\title{
SMEs and Industry 4.0 - Introducing a KPI based Procedure Model to identify Focus Areas in Manufacturing Industry
}

\author{
By Mario Kleindienst* \\ Christian Ramsauer ${ }^{\dagger}$
}

\begin{abstract}
Currently a paradigm shift in manufacturing industry is claimed. Driven by economic problems Industry 4.0 is hoped for being the solution to bringing back manufacturing to western economies. But especially SMEs tend to wait and see how this trend is developing. What is missing is a clear elaboration of Industry 4.0 specifically for SMEs. This paper elaborates the problems of SMEs with Industry 4.0 that mainly can be related to inherent characteristics like lack of resources. A procedure model is introduced, that mainly consists of 3 steps starting with an analysis of the status quo, where relevant data is gathered. Then KPIs are calculated that should further help to identify focus areas. Finally a decision based on the KPIs has to be made regarding the first steps towards Industry 4.0. This paper introduces the procedure model as well as a first draft of a criteria catalogue for deviating relevant KPIs.
\end{abstract}

Keywords: Industry 4.0, Investment need identification, Small and Medium-sized Enterprises.

\section{Introduction}

Since the economic crisis in 2008 , western economies are striving to set the foundations for industry to shift back to regions, where outsourcing of manufacturing industry was dominating during the past decades (European Commission 2012, European Commission 2014, Reshoring Initiative 2014). As countries with a high share of industry related earnings within the GDP, like Germany or Austria, overcame the crisis much easier, industry gains more and more on importance (Businesseurope 2014, McKinsey Global Institute 2012). But also companies have noticed that if manufacturing of their products is shifted to low cost regions, most of the times far away from their headquarters where research and development is done, innovation capabilities are also slipping away (Pisano and Shih 2012). Nevertheless the high costs of manufacturing in high cost countries remain (The Hackett Group 2012). With the application of so called cyber physical systems, vertical integration of several processes across value creation and highly data driven the fourth industrial revolution should enable both, highly efficient production of goods

\footnotetext{
* Scientific Assistant, Institute of Industrial Management and Innovation Research, Graz University of Technology, Austria.

${ }^{\dagger}$ Professor, Institute of Industrial Management and Innovation Research, Graz University of Technology, Austria.
} 
and a high degree of customization towards batch size one (Bauernhansl 2014). This means a dramatic increase of product- and process - complexity and an overall gain of importance of IT (Vogel-Heuser 2014). Especially small and medium sized companies have their problems with this new industrial revolution (Deloitte 2013). The reasons of that can be seen in the systeminherent characteristics of SMEs.

\section{Specifics of SMEs}

"A small business is not a little big business", Welsh and White stated in their Harvard Business Review article in July 1981 (Welsh and White 1981). What they pointed out was that mainly the resource poverty of SMEs makes the difference in how to approach SME's in comparison with their bigger counterparts. Since then various researchers investigated SME specific characteristics and the differences throughout the different company departments to larger companies (Stütz 2011, Pfohl 2013). If there is any key characteristic that describes the SME sector, it would be diversity. A oneperson company that offers services is called an SME in the same way as a high tech manufacturing company with 240 employees that delivers to the global market. In fact this paper and especially the specifics that are elaborated on the following pages describe more mid-sized companies that are acting within the manufacturing sector. This has to be stated as these specifics might not apply to the whole SME sector.

There has always been a debate on how to actually separate small and medium sized companies from larger ones. Nevertheless most countries and unions like the European Commission have set specific, quantifiable boundaries and use the number of employees in conjunction with annual turnover or balance sheet total to categorize companies by size (European Commission 2005). However, research has proved that this kind of differentiation is not accurate as it completely fades out qualitative criteria that would actually describe the differences between SMEs and large companies much better (Welter 2003). To describe these qualitative differences a company model is derived from several existing publications.

\section{Company Model}

Within this article we are focusing on manufacturing industry. Therefore it is important that the value creation process forms the center of the model. Porter has divided processes within the value chain into primary activities like inbound logistics, operations or distribution and supporting activities like human resources or technology development (Porter 1985). The new St. Galler management model also distinguishes between business and support processes and adds management processes (Rüegg-Stürm 2004) that according to Ulrich mainly deal with the creation, control and development of a target oriented sociotechnical organization (Ulrich 1984). Wohinz further describes the value 
creation process as the way of combining production factors on their transition from the procurement market to the sales market or customer and states purchasing as an important first process step in value creation (Wohinz 2003). The importance and integration of IT into the business process landscape can be seen as very diverging. There exist countless possibilities in companies how the IT department is interacting with other departments (Bartsch 2014). However, IT will become much more important in the future as digitization and informatisation of manufacturing will play a central role in the future (Ordanini 2006). Further important is the influence of different stakeholder groups. Wegmann has divided stakeholders of SMEs into 8 different groups that are company owner, management, employees, investors, suppliers, customer, competitors and the government (Wegmann 2013). Wohinz adds the society and cooperation partner (Wohinz 2003). Within the company model that is introduced in Figure 1, the stakeholders are divided into two groups. Those that get directly in contact with a company are dedicated to the direct environment. The broader environment contains competitors, the society, politics and research facilities. It has to be mentioned, that also stakeholders of the broader environment can directly interact with a specific company in exceptional cases, but these stakeholder mainly take influence on the company through intermediate entities.

Figure 1. Company Model

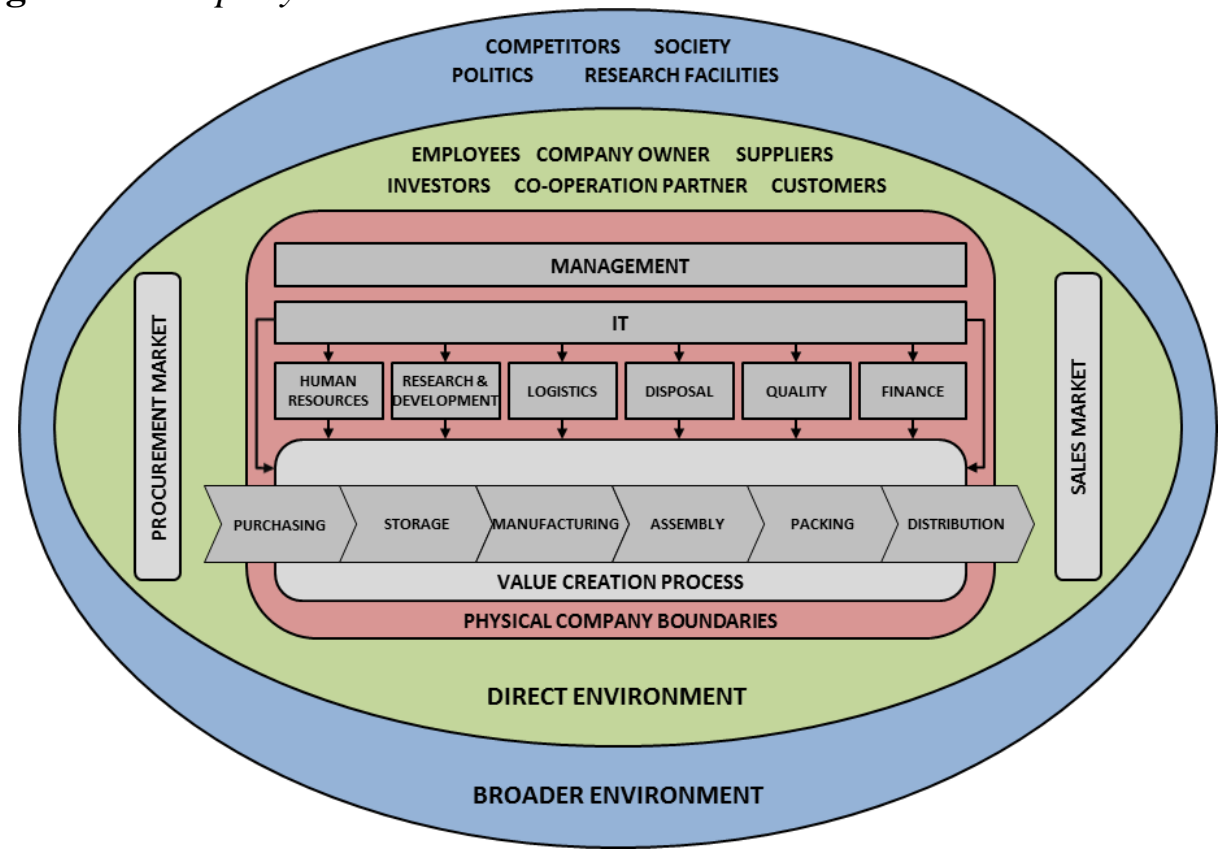

Characteristics of SMEs

Stütz has done an extensive review of numerous studies and publications about SMEs and their characteristics and concludes that most of the investigated literature uses quantitative criteria like the number of employees to distinguish between SMEs and large companies (Stütz 2011). He further points 
out, that only qualitative criteria facilitate an appropriate differentiation and lists those criteria based on his analysis (Stütz 2011). The investigation in this paper focusses on SMEs in the manufacturing industry sector and therefore the discussed characteristics may not fit to other sectors. However, the elaboration of SME related characteristics is important, in order to understand how SMEs actually work and how they could get affected from the fourth industrial revolution.

\section{$\underline{\text { Sales Market and Customers }}$}

Gantzel stated that the markets of SMEs exist where the largedimensioned production leaves gaps (Gantzel 1962). Mainly the ability to offer highly customized products is seen as one of the biggest advantages of SMEs (Krämer 2003). The markets that are served are predominantly regional and local and the customer relations are much more intense in comparison to large companies (Krämer 2003). Therefore the ability to react very quickly to changes in customer demand is attributed to SMEs very often (Schäfer and Zettelmeyer 1989). In general the proximity to customers can be seen as a main characteristic of SMEs (Schirrmann 2006).

\section{Production}

The ability of SMEs to quickly react on changes in customer demand is enabled through the high degree of flexibility in production (Zanger 2006). The dominant types of production are the single and small series production whereby mostly job shop production is applied (Fandel et al. 2009). Hence literature assumes that SMEs have to handle many production ramp ups, because of their production structure and cannot make use of economy of scale effects like large companies with mass production systems (Sihn et al. 2002, Fröhlich et al. 2000). Overall studies show that SMEs in general generate value much more labor intensive and use general-purpose machines instead of specialized ones (Mezgár and Kovács 1998). Workers in production of SMEs are attributed to have a high level of qualification (Schneider 2006).

\section{Procurement Market and Suppliers}

Due to the supposed characteristics of SMEs with production of small series and quick changes in product types it is assumed that also in procurement a lot of different supplies in small batch sizes have to be purchased (Hamer 1990). This leads to the effect, that volume discounts cannot be received as much as in larger companies and that the procurement power of SMEs is not very high (Hamer 1990). Further literature assumes that SMEs tend to source locally and only from a small amount of suppliers which they are very loyal to (Arnold 2006). SMEs more likely tend to stress the buffer function of storages in order to prevent shortages of the supply of production and to keep supply availability high (Deutschle 1995). 
Management and Organization

As the main characteristic of SMEs in organizational concerns flat hierarchies and rarely formalized structures are seen which are mostly tailored to the owner-manager and very much depend on him (Schneider 2006). This characteristic is often seen as one of the big advantages of SMEs because the short decision-making processes allow SMEs to act and react very quickly (Zanger 2006). Further managers of SMEs tend to have a much more personal relationship to their employees which in fact leads to a much more targeted assignment of employees and at the same time increases their sense of responsibility (Bickel 1981). Further employees in SMEs tend to have relatively bigger and much more diverse responsibilities than employees of larger companies (Arnold 2006). As a weakness of SMEs the lack of management capabilities and missing knowledge of appropriate methods for strategic planning is seen, as SMEs tend much more to intuitive and experience-based decision making (Schirrmann 2006).

\section{Human Resources}

Again, characteristics listed in this section cannot be true for the whole SME sector, as this sector is very diverse. By trend, SMEs tend to not having a separate organizational unit that exclusively deals with human resources (Olfert 2012). Strategic considerations in human resources are thought about not very often (Eisele and Doyé 2010). One of the biggest problems of SMEs is the low awareness level in comparison to larger companies that tend to practice active recruitment policies and therefore attract many of the "high potentials" (Hamel 2013). Overall Wegerich stated that SMEs have to constantly adapt their staff qualifications to the rapid changing circumstances in order to stay competitive and flexible (Wegerich 2011).

\section{Research and Development}

Meyer states that SMEs, much more than large companies, have to continuously bring new products to the market in order to compensate economy of scale effects of their larger counterparts (Meyer 2013). Therefore he claims that SMEs have to make a highly systematic and thoughtful use of their strongly limited personnel and financial resources and cannot accept many failures and meanders in R\&D (Meyer 2013). He further adds that SMEs very often tend to conduct joint research with other companies or research institutions or even buy $R \& D$ via license of mergers and acquisition activities (Meyer 2013).

$\underline{\text { IT }}$

Ordanini claims, that it is very rare to find the existence of a chief of information systems operations in SMEs (Ordanini 2006). This leads to the fact that decisions regarding IT are very often made by the entrepreneur or CEO him/herself along the way besides the daily business. On the other side she states that IT will become a central condition in the near future for SMEs and those SMEs should be aware of the importance of IT adoption (Ordanini 2006). 
Finance

Pfohl characterizes SMEs with no access to the anonymous capital market and therefore claims strongly limited financing possibilities (Pfohl 2013). Another disadvantage for SMEs in comparison to large companies is for him that during crises SMEs do not get much support from state or governments like large companies, simply because there are not so many jobs affected (Pfohl 2013). Regarding investment calculation methods Trost and Dechant summarized after an intensive literature review that SMEs tend to give much less attention to them as large companies and make decisions on investments very often intuitively (Trost and Dechant 2000).

\section{Industry 4.0}

The term "Industry 4.0" was mentioned for the first time in public at the Hannover fair in 2011 (VDI 2011). The aim of Industry 4.0 is to strengthen Western economies. Bauernhansl further claims, that in the future we will not have a problem on the demand side, but rather on the supply side (Bauernhansl 2014). In order to keep up with the growing demand on the one side and the limited resources on the other side it is necessary to facilitate a paradigm shift in how value creation is done in the future (Bauernhansl 2014). The "Platform Industry 4.0" therefore defined five central topics that are necessary for the fourth industrial revolution (Plattform Industrie 4.0 2015).

\section{Horizontal Integration over Value-creation Networks}

The integration of different IT-Systems that support or execute certain value creation processes like manufacturing, logistics, marketing, engineering or services within the boundaries of the own company as well as besides these boundaries, is necessary in order to facilitate new business models and flexible value creation networks with a division of work among all the participants of the network (Plattform Industrie 4.0 2015).

\section{Consistency of Engineering over the whole Lifecycle}

Herewith not only the engineering of the product is meant. Also the engineering process of the appropriate production system has to be included into all considerations. Therefore the lifecycle of the product contains besides the development process also the production process, the use of the product and the recycling or deconstruction of the product. Sub-topics are the integration of real and virtual or digital world and systems engineering (Plattform Industrie 4.0 2015).

\section{Vertical Integration and Cross-linked Production-systems}

In contrast to the horizontal integration over total networks, the third topic focusses on the integration of different IT-systems on different hierarchy levels 
of one production system from actuator- sensor-level, over the control and production-management level, the manufacturing and execution level until the company-planning level. As sub-topics the Platform Industry 4.0 mentions sensor-nets that facilitate for example condition monitoring of production systems and intelligence, flexibility and transformability of production systems (Plattform Industrie 4.0 2015).

\section{New Social Infrastructures of Work}

Hereby the interaction between humans and machines is mainly targeted. The aim is not to replace humans with machines anymore, but instead to make use of the great flexibility of human workers in manufacturing by implementing all sorts of assistance systems. But not only have the interactions between humans and machines to be rethought. Also interaction between humans on all different hierarchy levels throughout the whole value chain has to be considered. Further the technology acceptance and work design are central sub-topics of the work-infrastructures of the future. Current threads like demographic change and a shortage of skilled workers should therefore be in the center of workplace design considerations (Plattform Industrie 4.0 2015).

\section{Continuous Development of cross-sectional Technologies}

Within the whitepaper for industry 4.0 several cross-sectional technologies are listed that should together facilitate the successful implementation of the first four topics. Especially the net-communication of products, humans and machines worldwide, microelectronics to enable cyber physical systems for all kinds of applications, security, privacy and safety in components and systems of industry 4.0 scenarios, data analysis and big data approaches as well as syntax and semantics for industry 4.0 to enable a manufacturer-independent compatibility of different systems and technologies (Plattform Industrie 4.0 2015).

\section{Implications for SMEs}

The expected implications are structured according to the five topics of the platform industry 4.0. The direct consequences and challenges for SMEs are discussed. As these implications are based on numerous interviews with companies lead by the author, further sources are resigned in this chapter.

\section{Horizontal Integration over Value-creation Networks}

Maybe one of the biggest problems that SMEs are facing in this context is a lack of specialized IT personnel like stated above. Very often SMEs tend to develop very easy tools with standard software like Microsoft Excel. This leads to strongly differing software tools that can hardly be combined or at least interact with each other. This is already limiting enough within a single 
company, but makes interactions almost impossible between more companies. Therefore the first step towards a successful implementation of comprehensive IT systems is to define specific transfer parameters to enable an exchange of data among different departments and companies. Nevertheless completely horizontal integration over value creation networks is a vision in many cases. Fear of losing IP, missing standardization among SMEs and a lack of understanding of the possible advantages hinder SMEs to transfer this integration into practice. But the advantages cannot be neglected. The horizontal integration could facilitate new business models especially for SMEs. For example, if several free manufacturing capacities within a value creation network could be checked online and in real-time, customers could make use of these capacities and SMEs could increase their load factor. Especially for SMEs that tend to have all-purpose machines and labor that could adapt very quickly to new production orders this could be an interesting new way of providing manufacturing as a service. This is only one example of how SMEs could increase their turnover by horizontal integration. And of course there have to be a lot of things newly thought, but it can be foreseen, that this is a very good way of making use of one of the biggest advantages of SMEs: their flexibility.

\section{Consistency of Engineering over the whole Lifecycle}

The integration of real and digital world entails the implementation of simulation, planning- and descriptive models. Primarily SMEs do not make use of complex simulation tools or planning models, like elaborated above. In many cases none of the employees of an SME has experiences with such tools and therefore the possible advantages are often ignored. Nevertheless suppliers of simulation tools more and more tailor their systems to customers with inappropriate knowledge on simulation and design their systems in such a way, that even unexperienced users can get to very good results in a short amount of time. The biggest limiting factor why those systems are not disseminated among SMEs is the low level of awareness of such systems. Another factor that has to be taken into account when talking about the whole lifecycle is, that SMEs in many cases only act as a supplier of subassemblies and only sometimes really go the whole way down from development over production to disposal. This means again an increased complexity as SMEs are in many cases only one jigsaw piece.

\section{Vertical Integration and Cross-linked Production-systems}

Central within this topic the acquisition, manipulation and assessment of data can be seen. Therefore sensor nets are necessary that gather relevant data of for example production-, assembly-, logistics- or machine related data. For SMEs this would mean an increase of their flexibility if real-time data of the value creation process is available. For SMEs, that tend to use their existing machines for long periods of time, this would in many cases mean that they 
have to upgrade their existing equipment and place sensors at neuralgic points in the value creation process. Again many SMEs simply do not have the skills to on the one hand decide, where it would make sense to gather data and on the other hand run and maintain such a system of sensors. But still the vertical integration and the cross linked production systems contain advantages for SMEs. For example the throughput time could be drastically reduced if real time data of the production process is available.

New Social Infrastructures of Work

Multimodal assistance systems can be seen as a further means to increase flexibility of SMEs. As stated above, workers of SMEs tend to have very diverse tasks, whereby especially new workers are overstrained very often. With such assistance systems workers would have it easier to cope with the required tasks. Another effect is employability. Assistance systems target to make work tasks intellectual and physical easier performable. Thereby the population of possible work force gets increased dramatically. The SME can then choose the appropriate work force out of a much bigger selection. Especially topics like the demographic change or the shortage of skilled workers can be addressed herewith. For SMEs again the lack of knowledge of such systems as well as the required investment sums could be a limiting factor of this topic.

\section{Continuous Development of Cross-sectional Technologies}

SMEs will act more or less only as users of such technologies like cyber physical systems or big data algorithms and will in most cases not actively participate in the development of such technologies. Nevertheless new business ideas and models could emerge if SMEs rethink their value creation processes and enhance it with cross-sectional technologies like stated above. As these technologies should facilitate the first four fields of action further details regarding the impact of cross sectional technologies are not deemed necessary at this point.

\section{Procedure Model to Identify Investment-Need}

After the brief elaboration of SME specific characteristics and Industry 4.0 a rough version of the procedure model to identify the need for action for SMEs is introduced. 
Figure 2. Procedure Model

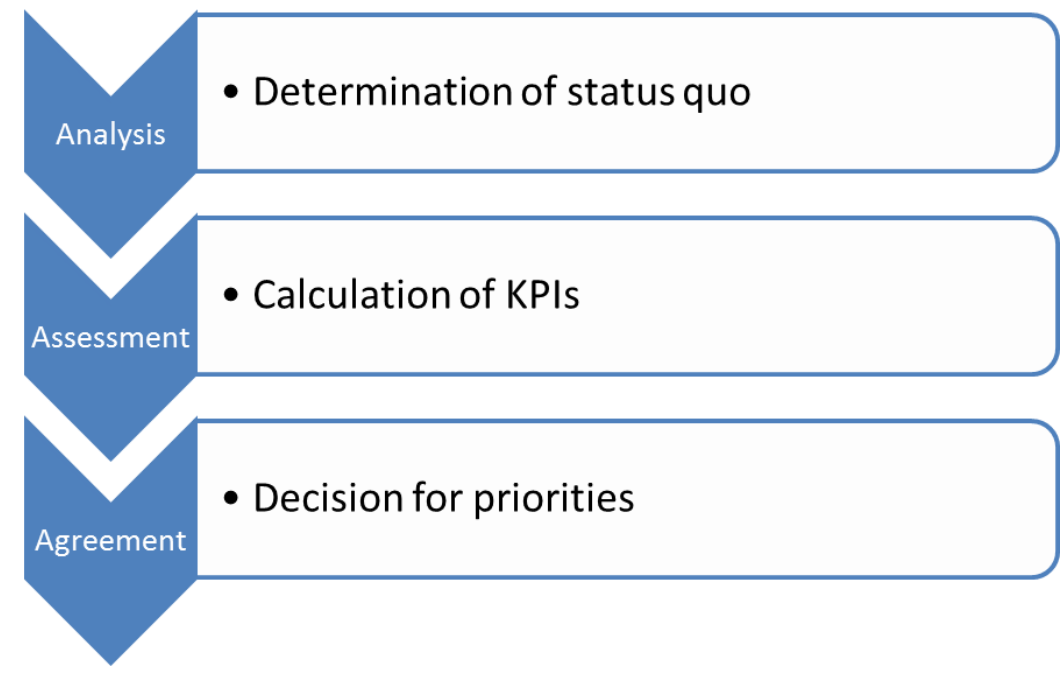

The procedure model is based on a three step approach like illustrated in Figure 2. The first step is the analysis of the status quo. During this first phase specific data has to be gathered that is necessary to calculate the KPIs in phase 2. The KPIs should be consciously chosen to fit the characteristics of SMEs. Therefore it has to be made sure that only data is needed that is commonly available in SMEs or at least not too complex to be determined. For each of the five central topics of Industry 4.0 that are elaborated above, specific criteria have to be evaluated. In this paper a first draft of these criteria is introduced in Table 1.

Table 1. Criteria to Determine Focus of Attention

\begin{tabular}{|l|l|}
\hline \multicolumn{1}{|c|}{ Industry 4.0 topic } & \multicolumn{1}{c|}{ Criteria } \\
\hline $\begin{array}{l}\text { Horizontal Integration over Value- } \\
\text { creation Networks }\end{array}$ & $\begin{array}{l}\text { Manufacturing load factor (machines, } \\
\text { labor) }\end{array}$ \\
\hline $\begin{array}{l}\text { Consistency of Engineering over the } \\
\text { whole Lifecycle }\end{array}$ & $\begin{array}{l}\text { Product complexity and number of } \\
\text { influenceable steps of value creation } \\
\text { chain }\end{array}$ \\
\hline $\begin{array}{l}\text { Vertical Integration and cross-linked } \\
\text { Production-systems }\end{array}$ & $\begin{array}{l}\text { Complexity of internal value creation } \\
\text { process }\end{array}$ \\
\hline New social Infrastructures of Work & $\begin{array}{l}\text { Degree of automation and complexity of } \\
\text { work tasks }\end{array}$ \\
\hline $\begin{array}{l}\text { Continuous Development of cross- } \\
\text { sectional Technologies }\end{array}$ & \\
\hline
\end{tabular}

As the aim of the first topic, horizontal integration over value creation networks, is to enable SMEs to share for example manufacturing capacity, it is reasonable to determine, if there are any free capacities available. The second topic, consistency of engineering over the whole lifecycle, is most useful for SMEs that take influence on more steps of the value creation process and create very complex products. This does not mean that it could not be valuable 
for other SMEs as well but for the purpose of setting clear priorities these companies should focus on this area first. Vertical integration and cross-linked production systems especially make sense if the internal value creation process is very complex. Otherwise the necessary effort would exceed the possible advantages. For the decision if new social infrastructures of work should be the first focus, the degree of automation and the complexity of work tasks should be evaluated. The less automated and the more complex the work tasks are, the more valuable multimodal assistance systems are. For the fifth topic, cross sectional technologies, no criteria are given, as this topic should only support the four others and cannot be implemented as a single topic. Out of these criteria KPIs have to be deviated in order to facilitate a targeted identification of the necessary focus area.

\section{Conclusions and Outlook}

After the elaboration of the specific characteristics of SMEs the direct implications for SMEs because of Industry 4.0 were elaborated. The procedure model, introduced in this paper, is a rough draft of how an SME could determine, whether Industry 4.0 makes sense and furthermore, which part should be tackled first. In comparison to existing models the KPI approach introduced in this paper is completely new. As a next step, the KPI set will be enhanced and completed and the limit-values of the KPIs that actually indicate a need for action in each specific field have to be set. This will be done together with industry within a survey with followed qualitative interviews. The results are planned to be available by the end of this year.

\section{References}

Arnold U (2006) Beschaffung [Procurement]. In HC Pfohl, (Edn.) Betriebswirtschaftslehre der Mittel- und Kleinbetriebe: Größenspezifische Probleme und Möglichkeiten zu ihrer Lösung [Business administration of small and medium enterprises: Sizes specific problems and suggestions for resolving them $] .4^{\text {th }}$ Edition. Grundlagen und Praxis der Betriebswirtschaft No. 44. Berlin.

Bartsch S (2014) Ein Referenzmodell zum Wertbeitrag der IT [A reference model for value contribution of IT]. In P Alpar, U Hasenkamp (Edn.) Entwicklung und Management von Informationssystemen und intelligenter Datenauswertung [Development and management of information systems and intelligent data analysis]. Wiesbaden: Springer Verlag.

Bauernhansl T (2014) Die Vierte Industrielle Revolution - Der Weg in ein wertschaffendes Produktionsparadigma [The Fourth Industrial Revolution - The road to a value-creating production paradigm]. In T Bauernhansl, $\mathrm{M}$ ten Hompel, B Vogel-Heuser (Edn.) Industrie 4.0 in Produktion, Automatisierung und Logistik [Industry 4.0 in production, automation and logistics]. Wiesbaden: Springer Fachmedien. 
Bickel W (1981) Der gewerbliche Mittelstand heute - Definition und Einordnung [The industrial middle class today - Definition and classification]. Zeitschrift für Organisation [Journal of Organization] 50(4).

Businesseurope (2014) Industry matters - Recommendations for an industrial compact. Retrieved from http://goo.gl/DgFuxX.

Deloitte (2013) Digitalisierung im Mittelstand. Aus der Studienserie "Erfolgsfaktoren im Mittelstand" [Digitization in the SME sector. The study series "Success Factors in the SME sector"]. Retrieved from http://goo.gl/bsgYSp.

Deutschle U (1995) Prozeßorientierte Organisation der Auftragsabwicklung in mittelständischen Unternehmen [Process-oriented organization of the order processing in medium-sized enterprises]. Berlin.

Eisele D, Doyé T (2010) Praxisorientierte Personalwirtschaftslehre [Practical Human Resource Management $]$. $7^{\text {th }}$ Edition. Stuttgart.

European Commission (2014) Commission calls for immediate action for a European Industrial Renaissance. Press release. Brussels 2014. Retrieved from http://goo.gl/9wW8z3.

European Commission (2012) Communication from the Commission to the European Parliament, the Council, the European Economic and Social Committee and the Committee of the Regions - A Stronger European Industry for Growth and Economic Recovery. Industrial Policy Communication Update. Brussels 2012. Retrieved from http://goo.gl/CkRFuo.

European Commission (2005) The new SME definition - User guide and model declaration. Retrieved from http://goo.gl/PuBr.

Fandel G, Fistek A, Stütz S (2009) Produktionsmanagement [Production Management]. Berlin.

Fröhlich E, Pichler JH, Pleitner HJ (2000) Größe in der Kleinheit [Size in the smallness]. In JH Pichler, HJ Pleitner, KH Schmidt (Edn.) Management in KMJDie Führung von Klein- und Mittelunternehmen [Management in SMEs - The management of small and medium-sized enterprises]. $3^{\text {rd }}$ Edition. Bern.

Gantzel KJ (1962) Wesen und Begriff der mittelständischen Unternehmung. Abhandlungen zur Mittelstandsforschung [Nature and concept of medium-sized businesses. Essays on the SME Research]. No. 4. Köln

Hamel W (2013) Personalwirtschaft [Human Resources]. In HC Pfohl (Edn.) Betriebswirtschaftslehre der Mittel- und Kleinbetriebe: Größenspezifische Probleme und Möglichkeiten zu ihrer Lösung [Business administration of small and medium enterprises: Sizes specific problems and suggestions for resolving them $] .5^{\text {th }}$ Edition. Grundlagen und Praxis der Betriebswirtschaft No. 44. Berlin.

Hamer E (1990) Mittelständische Unternehmen: Gründung, Führung, Chancen, Risiken [Medium-sized companies: foundation, leadership, opportunities, risks]. Landsberg am Lech: Deutsches Institut für Mittelstandsökonomie Magdeburg.

Krämer W (2003) Mittelstandsökonomik: Grundzüge einer umfassenden Analyse kleiner und mittlerer Unternehmen [SME Economics: Principles of a comprehensive analysis of SMEs]. München.

McKinsey Global Institute (Ed.) (2012) Manufacturing the future: The next era of global growth and innovation. New York. Retrieved from http://goo.gl/Cr9g3U.

Meyer J-A (2013) Innovationsmanagement [Innovation Management]. In HC Pfohl (Edn.) Betriebswirtschaftslehre der Mittel- und Kleinbetriebe: Größenspezifische Probleme und Möglichkeiten zu ihrer Lösung [Business administration of small and medium enterprises: Sizes specific problems and suggestions for resolving them $] .5^{\text {th }}$ Edition. Grundlagen und Praxis der Betriebswirtschaft No. 44. Berlin. 
Mezgár I, Kovács GL (1998) Co-Ordination of SME Production Through a CoOperative Network. Journal of Intelligent Manufacturing 9(2).

Olfert K (2012) Personalwirtschaft [Human Resources]. 15 ${ }^{\text {th }}$ Edition. Herne.

Ordanini A (2006) Information Technology and Small Businesses - Antecedent and Consequences of Technology Adoption. Cheltenham: Edward Elgar Publishin Ltd.

Pfohl HC (2013) Abgrenzung der Klein- und Mittelbetriebe von Großbetrieben [Delimitation of SMEs by large companies]. In HC Pfohl (Edn.) Betriebswirtschaftslehre der Mittel- und Kleinbetriebe - Größenspezifische Probleme und Möglichkeiten zu ihrer Lösung [Business administration of small and medium enterprises - sizes Specific Problems and suggestions for resolving them $] .5^{\text {th }}$ Edition. Berlin: Erich Schmidt Verlag.

Pisano GP, Shih WC (2012) Does America really need manufacturing? Harvard Business Review March.

Plattform Industrie 4.0 [Platform industry 4.0] (2015) Industrie 4.0 - Whitepaper FuE-Themen. Retrieved from http://goo.gl/q9A1kV.

Porter ME (1985) Competitive Advantage. New York: The Free Press.

Reshoring Initiative (2014) Reshoring Initiative Data Report: Reshoring and FDI Boost US Manufacturing in 2014. Illinois 2014. Retrieved from http://goo.gl/taiGbu.

Rüegg-Stürm J (2004) Das neue St. Galler Management-Modell [The new St. Gallen Management Model]. In R Dubs, D Euler, J Rüegg-Stürm, CE Wyss (Edn.) Einführung in die Managementlehre [Introduction to Management Theory]. $1^{\text {st }}$ Edition. Bern: Teile A-E. Haupt Verlag.

Schäfer D, Zettelmeyer B (1989) Produktion [Production]. In HC Pfohl (Edn.) Betriebswirtschaftslehre der Mittel- und Kleinbetriebe: Größenspezifische Probleme und Möglichkeiten zu ihrer Lösung [Business administration of small and medium enterprises: Sizes specific problems and suggestions for resolving them]. $2^{\text {nd }}$ Edition. Grundlagen und Praxis der Betriebswirtschaft No. 44. Berlin.

Schneider HM (2006) Produktionsmanagement [Production Management]. In HC Pfohl, (Edn.) Betriebswirtschaftslehre der Mittel- und Kleinbetriebe: Größenspezifische Probleme und Möglichkeiten zu ihrer Lösung [Business administration of small and medium enterprises: Sizes specific problems and suggestions for resolving them]. $4^{\text {th }}$ Edition. Grundlagen und Praxis der Betriebswirtschaft No. 44. Berlin.

Schirrmann E (2006) Marketing und Vertrieb - Unternehmenserfolg durch Kundenorientierung und Flexibilität [Marketing and Sales - Corporate success through customer orientation and flexibility]. In W Krüger, G Klippstein, R Merk, V Wittberg (Edn.) Praxishandbuch des Mittelstands: Leitfaden für das Management mittelständischer Unternehmen [Praxishandbuch of SMEs: A Guide for the Management of SMEs]. Wiesbaden.

Sihn W, Abele T, Oswald H (2002) Anlaufmanagement für den Mittelstand [Anlaufmanagement for SMEs]. Maschinenmarkt MM - das Industriemagazin No. 3.

Stütz S (2011) Kleine und mittlere Industrieunternehmen in der ökonomischen Theorie [Small and medium-sized industrial enterprises in economic theory]. In J-A Meyer (Edn.) Kleine und mittlere Unternehmen [Small and medium enterprises]. Köln: Band 22. JOSEF EUL VERLAG GmbH.

The Hackett Group (2012) Reshoring Global Manufacturing: Myths and Realities. Study Results Analysis. Retrieved from http://goo.gl/cg1ePA. 
Trost R, Dechant H (2000) Investitionsprozesse und Investitionsrechnung [Investment processes and investment appraisal]. In $\mathrm{H}$ Schneider (Edn.) Produktionsmanagement in kleinen und mittleren Unternehmen [Production management in small and medium enterprises]. Stuttgart.

Ulrich H (1984) Management. Bern: Haupt Verlag.

VDI (2011) Industrie 4.0: Mit dem Internet der Dinge auf dem Weg zur 4. Industriellen Revolution [Industry 4.0: The Internet of Things on the way to the 4th Industrial Revolution]. Retrieved from http://goo.gl/GtwQ4O.

Vogel-Heuser B (2014) Herausforderungen und Anforderungen aus Sicht der IT und der Automatisierungstechnik [Challenges and requirements from the perspective of IT and automation technology]. In T Bauernhansl, M ten Hompel, B VogelHeuser (Edn.) Industrie 4.0 in Produktion, Automatisierung und Logistik. Springer Fachmedien [Industry 4.0 in production, automation and logistics]. Wiesbaden: Springer Fachmedien.

Wegerich C (2011) Strategische Personalentwicklung in der Praxis [Strategic HR Development in practice]. $2^{\text {nd }}$ Edition. Weinheim.

Wegmann J (2013). Betriebswirtschaftslehre mittelständischer Unternehmen Praktiker-Lehrbuch [Business Administration medium-sized enterprises Praktiker textbook]. München: Oldenbourg Wissenschaftsverlag.

Welsh JA, White JF (1981) A small business is not a little big business. Harvard Business Review 59(4/July/August).

Welter F (2003) Strategien, KMU und Umfeld: Handlungsmuster und Strategiegenese in kleinen und mittleren Unternehmen [Strategies, SMEs and environment: patterns of action and strategy genesis in small and medium enterprises]. In Schriften des Rheinisch-Westfälischen Instituts für Wirtschaftsforschung [Writings of the Rhenish-Westphalian Institute for Economic Research]. Issue 69. Berlin: Drucker \& Humboldt.

Wohinz JW (2003) Industrielles Management - Das Grazer Modell [Industrial Management - The Grazer Model]. Wien - Graz: Neuer Wissenschaftlicher Verlag.

Zanger C (2006) Marketing. In HC Pfohl (Edn.) Betriebswirtschaftslehre der Mittelund Kleinbetriebe: Größenspezifische Probleme und Möglichkeiten zu ihrer Lösung [Business administration of small and medium enterprises: Sizes specific problems and suggestions for resolving them $] .4^{\text {th }}$ Edition. Grundlagen und Praxis der Betriebswirtschaft No. 44. Berlin. 